\title{
Isolation and phenotypic characterization of rhizobia that nodulate cowpea in the Cerrado in Tocantins State, Brazil
}

\author{
Aloisio Freitas Chagas Júnior, ${ }^{1, *}$, Luiz Antônio de Oliveira ${ }^{2}$, Henrique Guilhon de Castro ${ }^{1}$, \\ Gabriel de Lima Cornélio ${ }^{1}$, Gil Rodrigues dos Santos ${ }^{1}$, Lillian França Borges Chagas ${ }^{1}$, \\ Jefferson da Luz Costa ${ }^{3}$
}

\begin{abstract}
Depending on the nutritional characteristics and hardiness, the cowpea has become an important source of protein in North and Northeast regions of Brazil. The cowpea benefits from biological nitrogen fixation (BNF) and may receive part of the nitrogen needed for culture via symbiosis, which reduces production costs. Aiming to contribute to the optimization of the BNF in the culture of cowpea (Vigna unguiculata (L) Walp) in the cerrado of Tocantins, through the effectiveness of populations and diversity of rhizobia obtained in seven areas with and without crops , phenotypic isolation and characterization were performed $(\mathrm{pH}$, time of growth characteristics of the colonies and mucus). We obtained 72 rhizobia and evaluated in a dendrogram showed a great diversity, with the formation of 18 groups and the five large groups with $70 \%$ similarity. The study of morphological and physiological characteristics reveals a fairly wide diversity of rhizobia and is usually related to studies at the DNA level.

KEYWORDS: Vigna unguiculata, Nodulation, Nitrogen Fixation.
\end{abstract}

\section{Isolamento e caracterização fenotípica de rizóbios que nodulam feijão caupi no Cerrado do Tocantins, Brasil}

\section{RESUMO}

Em função das características nutricionais e de rusticidade, o feijão caupi tornou-se importante fonte de proteína nas regiões Norte e Nordeste do Brasil. O feijão caupi se beneficia da fixação biológica do nitrogênio (FBN) e pode receber parte do nitrogênio necessário para a cultura via simbiose, o que reduz os custos de produção. Com o objetivo de contribuir com a otimização do processo de FBN na cultura do feijão caupi (Vigna unguiculata (L) Walp) no cerrado do Tocantins, através da efetividade de populações e diversidade de isolados de rizóbio obtidos em sete áreas com e sem cultivos agrícolas, foram realizados isolamento e caracterização fenotípicas (pH do meio, tempo de crescimento, características das colônias e de muco). Foram obtidos 72 isolados de rizóbio e avaliados em um dendrograma onde mostraram uma grande diversidade com a formação de 18 grupos e cinco grandes grupos com similaridade de $70 \%$. O estudo das características fisiológicas e morfológicas revela uma diversidade bastante ampla dos isolados de rizóbio e costuma estar relacionado com estudos em nível de DNA.

PALAVRAS-CHAVE: Vigna unguiculata, Nodulação, Fixação de nitrogênio.

\footnotetext{
*Author for correspondence

1,* Departament of Agricultural Sciences and Technology; Federal University of Tocantins; P.O Box 77402-970; Gurupi - TO - Brazil, chagasjraf@uft.edu.br

${ }^{2}$ National Institute of Amazonian Research - INPA/CPCA; 69011-970; Manaus - AM - Brazil.

${ }^{3}$ Department of Bioprocess Engineering and Biotechnology, Federal University of Parana; Curitiba - Brazil.
} 


\section{INTRODUCTION}

The cowpea (Vigna unguiculata L. Walp.) Is a legume most widely adapted, versatile and nutritious. It has become an important agricultural product for Its nutritional characteristics, representing an alternative source of protein, one of the main products of support for low-income population (Freire Filho, 2005). Grown mainly in the North and Northeast, with $70 \%$ of national production, has an average yield of $400 \mathrm{~kg} \mathrm{ha}^{-1}$. This low production is due to the type of production system adopted by small farmers under the subsistence level, with little technification (Freire Filho, 2005). However, in field tests, it can be observed that the production can be increased (Martin et al., 2003; Zilli et al., 2006; Chagas Jr. et al., 2010).

One of the most limiting factors to productivity of cowpea is low in nutrients avaliability, especially $\mathrm{P}$ and $\mathrm{N}$ in agricultural soils. Nitrogen addition of fertilizers is expensive and in many cases, less efficient, particularly due to loss of the element caused by inadequate cultural practices (Ahmed et al., 2003). Some authors advocate the nitrogen in crops such as beans (Franco et al., 2008), which state that the yield increases by over $150 \%$ in use in seeding and / or coverage in no-till systems. However, this is a practice that increases the cost of production, no longer economically viable for most farmers who grow crops such as cowpea under subsistence. New technologies have been developed in order to improve productivity and quality of cowpea. Among these technologies, there is the biological nitrogen fixation (BNF) which is becoming more popular among farmers, especially in the Cerrado (Martins et al., 2003; Zilli et al., 2008; Chagas Jr et al., 2010). Due to the ecological and economic importance of rhizobia, the diversity of these bacteria has been investigated extensively and rizobiana taxonomy has undergone significant changes over the past three decades (Liu et al., 2005). The economic potential has not yet been fully determined, although rhizobial inoculation represent a viable alternative because of problems with the inoculant, which involve, among other things, the sensitivity of the strains inoculated abiotic and biotic stresses.

Considering the cerrado in the State of Tocantins, in particular southern state, factors such as temperature, genetic characteristics inherent to the symbionts, and interacting with climatic characteristics influence the persistence of rhizobia in the soil, limiting both the nodulation and nitrogen fixation (Chagas Jr. et al., 2012). To overcome these limitations, it is very important the choice of native strains of the area to be inoculated.

The knowledge of the diversity of rhizobia is of paramount importance and is considered a source of genetic resources for selection of strains adapted to different conditions. Currently, the system of microbial taxonomy addresses a joint analysis of morphological, physiological and different molecular tools, using statistical methods to evaluate the differences and similarities among microorganisms, providing quantitative measures of similarities among microorganisms. The taxonomy of rhizobia has changed in recent years in view of the use of molecular tools allowing the identification of new groups of bacteria capable of nodulation and nitrogen fixation in legumes (Chen et al., 2005). However, to obtain morphological and physiological characteristics of rhizobia has been used to identify new groups of rhizobia.

The study of the bacteria diversity based on of cultural characteristics (morphological and physiological), involves the evaluation of parameters such as the time it takes the bacteria to form individual colonies in culture, colonies of the diameter, shape, color, production of acid and alkali and mucus production, among others (Martin et al., 1997). These phenotypic methods of analysis of cultural characteristics of microorganisms have the advantage of being fast, allowing a preliminary analysis of diversity. Thus, the aim of this study was to characterize the morphological diversity of rhizobia isolated 
from nodules of cowpea grown in soil samples collected in the Cerrado in Tocantins.

\section{MATERIALS AND METHODS}

Soil samples were collected from a 0-20 cm layer in the regions of Gurupi, Natividade, Pedro Afonso, Cariri and Lagoa da Confusão, in areas with and without crops in the State of Tocantins. The soil samples collected served as a source of inoculum in seeds of cowpea (Vigna unguiculata L. Walp.) As a trap plant for isolation of rhizobia from nodules (Xavier et al., 1997). Assays were performed in a greenhouse at the Experimental Station of the Federal University of Tocantins (FUT), University Campus of Gurupi. It were used subsamples soil equivalent to $30 \mathrm{~g}$, to serve as a source of inoculum populations and evaluate the population of the samples Rhizobium. The substrate used was sand (autoclaved at $120^{\circ} \mathrm{C}$ for 2 hours), which was added to sterile vessel with a capacity of $700 \mathrm{~g}$ of substrate. The subsamples of soil were placed in the center of the pot containing sand autoclaved.

Were seeded eight seeds per pot (previously rinsed seeds with $92 \%$ ethanol for 30 seconds and the surface sterilized with $0.2 \%$ sodium hypochlorite for 4 minutes and rinsed with sterile water to remove hypochlorite solution), trying to put them in contact with the soil sample to germinate, the seeds could be infected by Rhizobium populations present in the same. On the seventh day after germination, thin leaving three plants per pot.

The vessels received a solution containing all nutrients except nitrogen (Norris and Date, 1976), pH 5.5. Nutrient solution was added periodically over the cycle of the plants, placed on sterile distilled water as necessary. We used three pots for each soil sample containing three plants per pot, nine plants per soil sample.

The plants were harvested at early stages of flowering (approximately 45 days after the onset of germination).

It was isolated the rhizobia present in samples, after collection of nodes using the traditional method described by Vincent (1970) and
Somasegaran and Hoben (1985), where they were washed with ethanol $(92 \%$ for 30 seconds) following a disinfection surface with sodium hypochlorite (4 minutes) and ten washes with sterile water. Then the nodules were pressed with a clamp and then scratching was performed in Petri dishes containing YMA (yeast mannitol agar) and bromothymol blue, $\mathrm{pH}$ 6.0. After isolation, the plates were incubated at $28^{\circ} \mathrm{C}$ until the growth of colonies of bacteria, when they were transplanted into new plates containing the same medium and incubated again until new bacterial growth. The isolates obtained were kept in test tubes containing the YMA inclined. Thus it was created the germoplasm bank of Rhizobium of FUT for subsequent selection of strains with desirable agronomic characteristics.

Phenotypic characterization was performed according to Vincent (1970) and Martins et al. (1997) evaluating the time of growth of each of the isolates, separating slow-growing bacteria (4 days before) and rapid (three days), the $\mathrm{pH}$ of the medium after growth of bacteria was observed indirectly by coloring medium containing bromothymol blue (alkaline, acid and neutral), the shape of the colony (circular or irregular), transparency and color of the colony. The mucus produced by the cells were assessed both: amount (high or low), adherence to the Platinum strap, observed by the removal of mucus from the surface of the culture medium (yes or no) and elasticity, observed at the time of removal of mucus from the culture medium (yes or no).

The method used for delimitation of dissimilarity of isolated groups was the complete linkage method and for the calculation of the genetic distance was obtained the average Euclidean distance. We used the criterion of Singh to identify the relative contribution of each trait to the diversity among the isolates. Statistical analysis was done on the SSAG program (System for statistical analysis and genetic). 


\section{RESULTS AND DISCUSSION}

Initially there was obtained 72 representative isolates from soil collected in the various regions which are presented quite heterogeneous in their morphological and physiological characteristics (Table 1).

With the data of morphological characterization, we constructed a dendrogram of similarity among the isolates. Therefore, initially they were classified according to the morphological characteristics and groups were used in the analysis of isolates with $100 \%$ similarity (Tables 2 and 3), used for construction of the grouping. After analysis of the dendrogram, considering the percentage of $70 \%$ similarity, it was possible the formation of five large groups of isolates (Figure 1), the first being formed of four groups (Groups 1, 3, 11 and 13), the second formed of six groups (Groups 2, 4, 7, 12, 10 and 15), the third, four groups (Groups 5, 18, 8 and 16), the fourth, three groups (Groups 6, 9 and 14) and fifth isolated by a group (Group 17). Analysis of similarity with morphological and physiological parameters of rhizobial isolates from soil samples from different regions, also showed wide diversity (Germano et al., 2003; Zilli et al., 2004, Silva et al ., 2006; Chagas Jr., 2007).

The shape of the colony is dependent on the presence of mucus, which is very common in the genus Bradyrhizobium. The consistency of the mucus produced is also quite varied, especially in fast-growing isolates. While some colonies which have gummy aspect, others are aqueous with mucus coming to coalesce all over the plate, reaching across the plate, making it difficult to isolate a colony after a few days. The isolates that showed rapid growth and, more generally, with acid reaction in culture medium obtained in areas of cerrado suggest greater adaptability to this condition (Table 2).

The bacteria that nodulate cowpea have been routinely considered as belonging to the miscellaneous group "cowpea" or Bradyrhizobium spp., comprising a large number of slow-growing strains capable of nodulating several species of herbaceous legumes common in the tropical region (Saleena et al., 2001; Zilli et al., 2006). In this study, approximately $55 \%$ of isolates obtained from different regions collection showed rapid growth in culture medium indicating that the limit strain capable of Cowpea nodular goes beyond the group's Bradyrhizobium spp (Tables 2 and 3). Some studies already showed the fast-growing rhizobia are also able to induce nodules on cowpea (Zhang et al., 2007). The fast-growing rhizobia are more common in arid regions. This feature is a survival strategy, since they are more drought tolerant than slow-growing and multiply rapidly in a short period of wet weather, which would explain its greater frequency in soils of semiarid regions (Santos et al., 2007).

It were not obtained in this study, dried colonies isolated. All the isolates showed mucus production, although some have little mucus (Table 2). The mucus production would represent a mechanism involved in the process of adaptation and survival of Rhizobium in adverse conditions of soil and climate. According to Freitas et al. (2007), the lack of description of strains that produce an excess of using exopolysaccharides in literature caused some omission on this group of bacteria for quite some time, believing that contaminants. The mucus production changes the permeability of the cells, making strains more resistant to biotic factors of competition on the soil, as the presence of microorganisms promoters of antibiotics. Batista et al. (2007) observed trend of increased mucus production by Bradyrhizobium isolates, as a result of adaptation to conditions of acid soils of the Brazilian Cerrado.

Whereas the distribution of isolated by collection location of soil to isolate (Table 1), one can observe the similarity between the diverse isolates presented in different places of collection (Table 2, Figure 1), since parts of each of the isolated local grew rapidly, with a tendency to acidify the $\mathrm{pH}$ of the medium.

Cultural and morphological characteristics of bacterial species capable of forming nodules 
on legumes, generally identified as Rhizobium provide important information for their identification and grouping. Among many other features, such as the time of growth and reaction of $\mathrm{pH}$ in medium with yeast extract, mannitol, and mineral salts Agar (YMA) as physiological tests are significant in taxonomy of Rhizobium. Martins et al. (1997) describe the main features regarding growth in culture medium and colony morphology of Rhizobium, serving for the lifting of Rhizobium isolates that cowpea knowledge. Similarly for different regions and ecosystems as in the Cerrado of Roraima (Zilli et al., 2004), Amazonas State (Chagas Jr., 2007) e Paraíba (Silva et al., 2006).

Many of these phenotypic characteristics are studied with the aim not only of characterization, but to verify the likely ecological adaptability of different environmental conditions prevalent in the isolated ecosystem for which proceeds the Rhizobium inoculant-selection. In addition, we seek to correlate metabolic diversity data with the symbiotic efficiency, since that should reflect the diversity of the mechanisms of control of symbiotic interactions between different strains of Rhizobium and legumes.

The morphofisiological characterization allowed a greater knowledge of the population of soil rhizobia collected in this work, and the group will facilitate the development of the following steps to confirm the selection and efficient Rhizobium nodulation for fixing the N2 in varieties of Cowpea. According to Hameed et al. (2004), the study of physiological and morphological characteristics reveals a fairly wide diversity of Rhizobium isolates and is usually related to DNA-level studies. These data are important, since the knowledge of the indigenous communities through these or other techniques are critical to meet the diversity of species, primary resource for work in the area of biotechnology.

Isolates from Cowpea in different regions of China showed similarity to Rhizobium and
Sinorhizobium, Bradyrhizobium, 16S ribosomal gene molecular analysis (Zhang et al., 2007). These authors identified, still, insulated with similarities to Bradyrhizobium, but that differed from species currently described in the genus, signaling the possibility to belong to a species not yet characterized. The same was observed by Chagas Jr. (2007) with Rhizobium isolates from soils of the Amazon State, Brazil.

The results presented, demonstrated the low specificity of Cowpea in relation to microssimbionte to establish the nodulation and point the species as a good option as a host plant. In relation to selection of efficient strains in the process of converting atmospheric nitrogen into nitrogen compounds, should submit to native rhizobia competitiveness, since the species is promiscuous. In this sense, becomes of paramount importance the search of isolated from the region where if you want to cultivate the Cowpea in order to select the isolated adapted to environmental conditions, which invariably are, whether for reasons of adverse soil temperature, low fertility or mineral toxicity.

The cerrado regions has peculiar characteristics, with all its biodiversity in conditions of constant stress, temperature, low precipitation at certain times of the year or characteristics of soils of the region. These conditions can affect the survival and efficiency of rhizobia that ecosystem and it is possible that the high diversity observed is an indication of the capacity of the system to maintain the functional group under stresses; Therefore, the great diversity, considering the phenotypic characteristics of the isolates of rhizobia found in this region, obtained from the Cowpea used as host plant suggests stability of soils of this region and the nitrogen fixation, tolerating their stresses; This may be a result of adaptation of rhizobia along with the great diversity of native leguminous plants species in cerrado. 
Table 1. Location and soil samples collected in different forms of land use in counties in Tocantins State, used as a source of inoculum of Rhizobium isolates obtained from plants and cowpea.

\begin{tabular}{|c|c|c|c|}
\hline County/Area & Collection location & Soil / culture & Isolates \\
\hline 1. Gurupi: Area 1 & FUT & Physic nut (Jatropha curcas) & *FUT 02, FUT 03 \\
\hline \multirow{3}{*}{ 1. Gurupi: Area 2} & \multirow{3}{*}{ FUT } & Rice (Oryza sativa) & FUT R06, FUT R07 \\
\hline & & Sugarcane (Saccharum officinarum) & FUT R08, FUT R10 \\
\hline & & Sorghum (Sorghum bicolor) & FUT R11, FUT R12 \\
\hline \multirow{4}{*}{ 1. Gurupi: Area 3} & \multirow{4}{*}{ FUT } & Papaya (Carica papaya) & FUT R16 \\
\hline & & Banana (Musa paradisíaca) & FUT R20 \\
\hline & & Crotalaria (Crotalaria spp.) & FUT R22 \\
\hline & & Corn (Zea mays) & FUT R24 \\
\hline \multirow[t]{3}{*}{ 1. Gurupi: Area 4} & \multirow[t]{3}{*}{$\begin{array}{l}\text { Assesment Vale } \\
\text { Verde }\end{array}$} & Pumpkin (Cucurbita pepo) & FUT R28, FUT R29 \\
\hline & & Cowpea (Vigna unguiculata) & FUT R31 \\
\hline & & Forest & FUT R34, FUT R35 \\
\hline 1. Gurupi: Area 5 & $\begin{array}{l}\text { Vale Verde } \\
\text { settlement }\end{array}$ & Sugarcane (S. officinarum) & FUT R37 \\
\hline 1. Gurupi: Area 6 & $\begin{array}{l}\text { Vale Verde } \\
\text { settlement }\end{array}$ & Cowpea (V. unguiculata) & FUT R44, FUT R46 \\
\hline 1. Gurupi: Area 7 & $\begin{array}{l}\text { Vale Verde } \\
\text { settlement }\end{array}$ & Corn (Zea mays) & FUT R 47, FUT R48 \\
\hline \multirow[t]{2}{*}{ 1. Gurupi: Area 8} & \multirow[t]{2}{*}{$\begin{array}{l}\text { Vale Verde } \\
\text { settlement }\end{array}$} & Degraded pasture (Brachiaria brizantha) & FUT R49, FUT R50 \\
\hline & & Rice $(O$. sativa $)$ & FUT R54 \\
\hline \multirow[t]{2}{*}{ 1. Gurupi: Area 9} & \multirow[t]{2}{*}{$\begin{array}{l}\text { Vale Verde } \\
\text { settlement }\end{array}$} & Cowpea (V. unguiculata) & FUT R57, FUT R59 \\
\hline & & Corn (Z. mays) & FUT R63, FUT R64 \\
\hline \multirow[t]{2}{*}{ 2. Cariri: } & \multirow[t]{2}{*}{$\begin{array}{l}\text { Carioca farm, BR } \\
24212 \mathrm{~km}\end{array}$} & Cowpea (V. unguiculata) & FUT R67, FUT R69 \\
\hline & & Forest & FUT R72 \\
\hline \multirow[t]{7}{*}{ 3. Natividade } & \multirow[t]{7}{*}{ Agricultural School } & Degraded pasture (Brachiaria brizantha) & FUT R74, FUT R75, FUT R76 \\
\hline & & Soybean (Glycine max) & $\begin{array}{l}\text { FUT R77, FUT R78, FUT R79, } \\
\text { FUT R80 }\end{array}$ \\
\hline & & Cowpea (V. unguiculata) & $\begin{array}{l}\text { FUT R81, FUT R82, FUT R83, } \\
\text { FUT R84 }\end{array}$ \\
\hline & & Mucuna (Mucuna pruriens) & FUT R86, FUT R87, FUT R88 \\
\hline & & Leucaena (Leucaena leucocephala) & $\begin{array}{l}\text { FUT R89, FUT R90, FUT R91, } \\
\text { FUT R92 }\end{array}$ \\
\hline & & Forest & $\begin{array}{l}\text { FUT R93, FUT R94, FUT R95, } \\
\text { FUT R96 }\end{array}$ \\
\hline & & Forest & FUT R97 \\
\hline \multirow[t]{6}{*}{ 4. Pedro Afonso } & \multirow{6}{*}{$\begin{array}{l}\text { Cultivation area - } \\
\text { Pedro Afonso } \\
\text { Agricultural } \\
\text { cooperative }\end{array}$} & Soybean (Glycine max) & FUT R98, FUT R99 \\
\hline & & Soybean (G. max) & FUT R101, FUT R102 \\
\hline & & Soybean (G. max) & FUT R103 \\
\hline & & Forest & FUT R105, FUT R108 \\
\hline & & Crotalaria (Crotalaria juncea) & FUT R109, FUT R111, FUT R112 \\
\hline & & Forest & $\begin{array}{l}\text { FUT R113, FUT R114, FUT R115, } \\
\text { FUT R116 }\end{array}$ \\
\hline $\begin{array}{l}\text { Lagoa da } \\
\text { Confusão }\end{array}$ & $\begin{array}{l}\text { Bacaba farm, } \\
\text { Vicinal } 46\end{array}$ & Cowpea (V. unguiculata) & FUT R119, FUT R120 e FUT R121 \\
\hline
\end{tabular}

(1) No isolates were obtained from the soil samples.

*FUT - Federal University of Tocantins. 
Table 2 - Morphophysiological characteristics of groups of Rhizobium isolates obtained from soil samples from different regions of Tocantins State, Brazil.

\begin{tabular}{|c|c|c|c|c|c|c|c|c|c|}
\hline \multirow{2}{*}{ Groups/Number of Isolates ${ }^{1}$} & \multicolumn{9}{|c|}{ Isolated groups characteristics $/ 2^{2}$} \\
\hline & GT & $\mathrm{pH}$ & DC & $\mathrm{EC}$ & $\mathrm{Tr}$ & $\mathrm{CC}$ & EM & $\mathrm{TM}$ & $\mathrm{QM}$ \\
\hline Group 1 (20) & $\mathrm{F}$ & Ac & $>2$ & $\mathrm{H}$ & $\mathrm{S}$ & W & WE & Vis & M \\
\hline Group 2 (7) & $\mathrm{F}$ & Ac & $<2$ & $\mathrm{~F}$ & $\mathrm{~S}$ & $\mathrm{~W}$ & WE & Vis & M \\
\hline Group 3 (6) & $\mathrm{F}$ & Ac & $>2$ & $\mathrm{H}$ & $\mathrm{S}$ & $\mathrm{W}$ & $\mathrm{E}$ & Vis & M \\
\hline Group 4 (6) & $\mathrm{F}$ & Ac & $\leq 2$ & $\mathrm{H}$ & $\mathrm{S}$ & $\mathrm{W}$ & WE & Vis & M \\
\hline Group 5 (6) & $\mathrm{S}$ & $\mathrm{Al}$ & $\leq 2$ & $\mathrm{~F}$ & $\mathrm{~S}$ & $\mathrm{~W}$ & WE & Vis & M \\
\hline Group 6 (5) & $\mathrm{F}$ & Ac & $<2$ & $\mathrm{H}$ & $\mathrm{N}$ & $\mathrm{W}$ & $\mathrm{E}$ & But & M \\
\hline Group 7 (4) & $\mathrm{F}$ & $\mathrm{Ac}$ & $\leq 2$ & $\mathrm{~F}$ & $\mathrm{~N}$ & $\mathrm{~W}$ & WE & Vis & M \\
\hline Group 8 (3) & $\mathrm{F}$ & $\mathrm{Al}$ & $\leq 2$ & $\mathrm{~F}$ & $\mathrm{~S}$ & $\mathrm{~W}$ & WE & Vis & M \\
\hline Group 9 (2) & $\mathrm{S}$ & Ac & $<2$ & $\mathrm{H}$ & $\mathrm{N}$ & $\mathrm{W}$ & WE & But & $\mathrm{L}$ \\
\hline Group 10 (2) & $\mathrm{F}$ & Ac & $\leq 2$ & $\mathrm{~F}$ & $\mathrm{~S}$ & $\mathrm{Y}$ & WE & Vis & $\mathrm{M}$ \\
\hline Group 11 (2) & $\mathrm{F}$ & $\mathrm{Ac}$ & $>2$ & $\mathrm{~F}$ & $\mathrm{~N}$ & W & WE & But & M \\
\hline Group 12 (2) & $\mathrm{S}$ & $\mathrm{Ac}$ & $\leq 2$ & $\mathrm{H}$ & $\mathrm{S}$ & W & WE & Vis & M \\
\hline Group 13 (2) & $\mathrm{F}$ & Ac & $>2$ & $\mathrm{H}$ & $\mathrm{N}$ & $\mathrm{Y}$ & WE & Vis & M \\
\hline Group 14 (1) & $\mathrm{S}$ & Ac & $\leq 2$ & $\mathrm{H}$ & $\mathrm{N}$ & $\mathrm{W}$ & WE & But & M \\
\hline Group 15 (1) & $\mathrm{F}$ & $\mathrm{Ac}$ & $\leq 2$ & $\mathrm{~F}$ & $S$ & $\mathrm{Y}$ & WE & Vis & $\mathrm{L}$ \\
\hline Group 16 (1) & $\mathrm{F}$ & $\mathrm{Al}$ & $<2$ & $\mathrm{~F}$ & $\mathrm{~S}$ & W & WE & But & $\mathrm{L}$ \\
\hline Group 17 (1) & $\mathrm{S}$ & $\mathrm{Al}$ & $>2$ & $\mathrm{H}$ & $\mathrm{S}$ & $\mathrm{W}$ & $\mathrm{E}$ & But & $\mathrm{L}$ \\
\hline Group 18 (1) & $\mathrm{S}$ & $\mathrm{Al}$ & $<2$ & $\mathrm{~F}$ & $\mathrm{~S}$ & $\mathrm{~W}$ & WE & But & M \\
\hline
\end{tabular}

${ }^{1}$ Groups of isolates. ${ }^{2} \mathrm{TC}-$ Growth time (F: fast $\leq 3$ days, S: Slow > 3 days); $\mathrm{pH}$ of the medium (Ac: acid, Al: alkaline); DC - diameter of the colony in mm; IC - increase in colony (F: flat, H: high); Tr - transparency (S: yes, N: no); CC - color of the colony (Y: yellow, W: white); EM elasticity of mucus (WE: without elasticity, E: with elasticity); TM - type of mucus (Vis: viscous, But: butyric); QM - amount of mucus (M: much, L: little). 


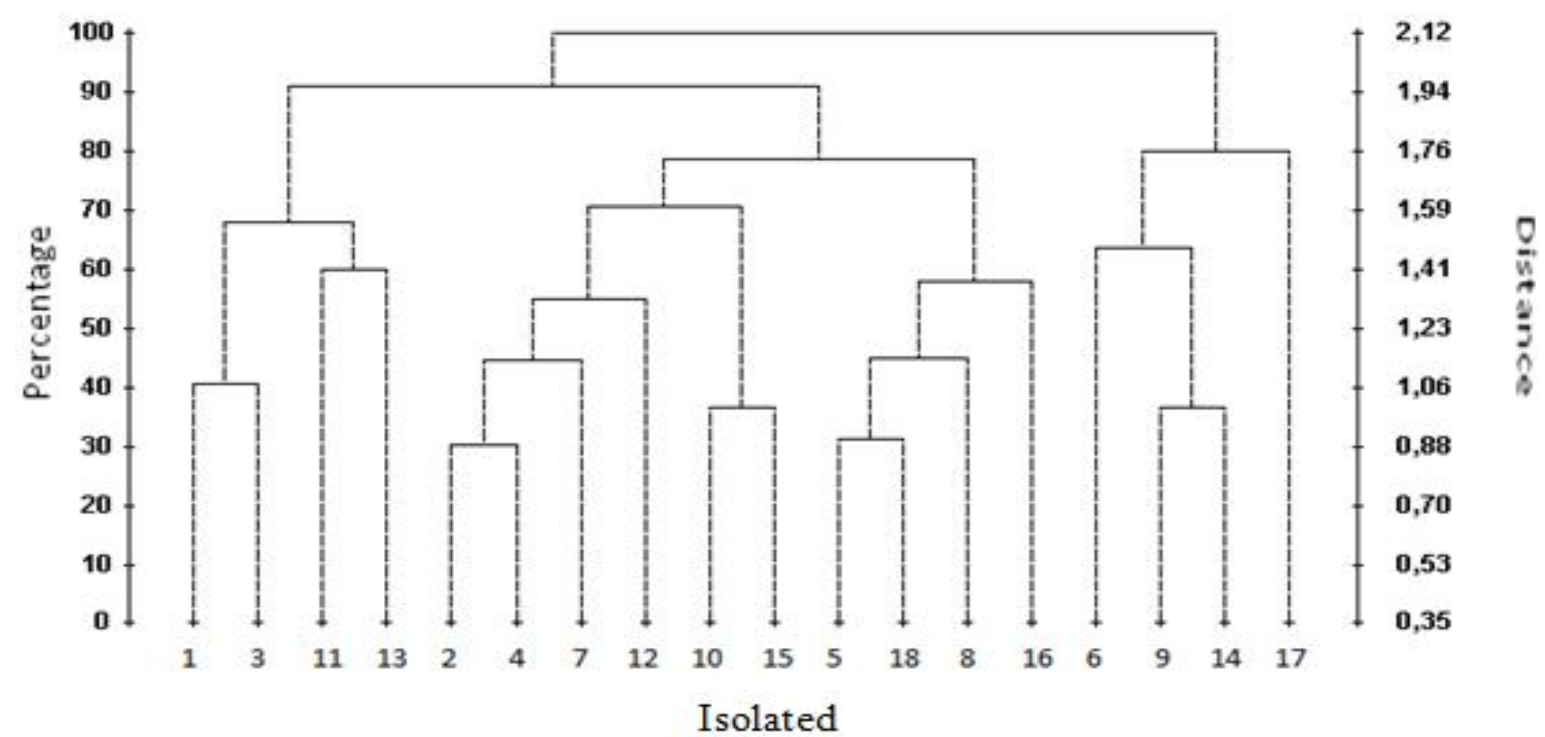

Figure 1 - Similarity dendrogram morphophysiological characteristics of groups of Rhizobium isolates studied.

Table 3. Groups of rhizobia isolated associated with cowpea according to morphophysiological characterization.

\begin{tabular}{ll}
\hline GG & Isolated \\
\hline Group 1 & *'FUT R64, FUT R72, FUT R74, FUT R75, FUT R78, FUT R81, FUT R82, FUT R83, FUT \\
& R84, FUT R86, FUT R88, FUT R89, FUT R92, FUT R96, FUT R98, FUT R99, FUT R102, FUT \\
Group 2 & FUT, FUT R115 e FUT R121 \\
Group 3 & FUT R46, FUT R63, FUT R76, FUT R94, FUT R97 e FUT R105 \\
Group 4 & FUT R22, FUT R35, FUT R57, FUT R79, FUT R90 e FUT R80 \\
Group 5 & FUT R31, FUT R 37, FUT R49, FUT R111, FUT R112 e FUT R113 \\
Group 6 & FUT R07, FUT R08, FUT R11, FUT R20 e FUT R24 \\
Group 7 & FUT R28, FUT R29, FUT R54 e FUT R95 \\
Group 8 & FUT R34, FUT R59 e FUT R67 \\
Group 9 & FUT R69 e FUT R120 \\
Group 10 & FUT R44 e FUT R48 \\
Group 11 & FUT R10 e FUT R101 \\
Group 12 & FUT R77 e FUT R93 \\
Group 13 & FUT R116 e FUT R119 \\
Group 14 & FUT R103 \\
Group 15 & FUT R91 \\
Group 16 & FUT R16 \\
Group 17 & FUT R87 \\
Group 18 & FUT R114 \\
\hline
\end{tabular}

*FUT - Federal University of Tocantins. 


\section{CONCLUSION}

The results of this study show that the areas collect soil samples indicate that rhizobial populations are quite diverse and diversity morphophysiological can indicate the occurrence of genetic diversity present in these soils.

\section{REFERENCES}

Alves, B.J.R.; Boddey, R.M.; Urquiaga, S. The success of BNF in soybean in Brazil. Plant and Soil, v. 252, p. 1-9, 2003.

Batista, J.S.S.; Hungria, M.; Barcellos, F.G.; Ferreira, M.C.; Mendes, I.C. Variability in Bradyrhizobium japonicum and B. elkanii seven years after introduction of both the exotic microsymbiont and the soybean host in a cerrados soil. Microbial Ecology, v. 53, n. 2, p. 270-284, 2007.

Chagas Jr., A.F. Características agronômicas e ecológicas de rizóbios isolados de solos ácidos e de baixa fertilidade da Amazônia. Tese de Doutorado. Universidade Federal do Amazonas UFAM/ Instituto Nacional de Pesquisas da Amazônia - INPA. 157p, 2007.

Chagas Jr., A.F.; Rahmeir, W.; Fidelis, R.R.; Santos, R.; Chagas, L. F. B. Eficiência agronômica de estirpes de rizóbio inoculadas em feijão-caupi no cerrado, Gurupi, TO. Revista Ciência Agronômica, v. 41, n. 4, p. 709-714, 2010.

Chagas Jr., A.F.; Santos, G. R.; Melo, R. C. L.; Oliveira, A. G.; Vizioli, B.; Chagas, L. F. B.; Costa, J.L. Effect of natural nodutation in the development of leguminous trees on soils of cerrado in Tocantins. Journal of Biotechnology and Biodiversity, v. 3, 1, p. 38-44, 2012.

Chen, W.M.; Faria, S.M.; Straliotto, R.; Pitard, R.M.; Simões-Araújo, J.L.; Chou, J.F.; Chou, Y.J.; Barrios, E.; Prescott, A.R.; Elliott, G.N.; Sprent, J.I.; Young, J.P.W., James, E.K. Proof that Burkholderia strains from effective symbioses with legumes: a study of novel mimosa-nodulation strains from South America. Applied and Environmental Microbiology, v. 71, n. 11, p. 7461-7471, 2005.
Coutinho, H.L.C.; Oliveira, V.M.; Lovato, A.; Maia, A.H.N.; Manfio, G.P. Evaluation of the diversity of rhizobia in Brazilian agricultural soils cultivated with soybeans. Applied Soil Ecology, v. 13, n. 2, p. 159-167, 1999.

Franco, E.; Andrade, C.A.B.; Scapim, C.A.; Freitas, S.L. Resposta do feijoeiro à aplicação de nitrogênio na semeadura e cobertura no sistema de plantio direto. Acta Scientiarum Agronomy, v. 30, n. 3, p. 427-434, 2008.

Freire Filho, F.R.; Lima, J.A.A.; Ribeiro, V.Q. Feijão caupi: avanços tecnológicos. Freire Filho, F.R.; Lima, J.A.A.; Ribeiro, V.Q (eds.). Brasília, DF. Embrapa Informações Tecnológicas. 519p, 2005.

Freitas, A.D.S.; Vieira, C.L.; Santos, C.E.R.S.; Stamford, N.P.; Lyra, M.C.C.P. Caracterização de rizóbios isolados de jacatupé cultivado em solo salino do Estado de Pernambuco, Brasil. Bragantia, v. 66, n. 3, p. 497-504, 2007.

Fuhrmann, J. Symbiotic effectiveness of indigenous soybean Bradyrhizobium as related to serological, morfhological, rhizobitoxine and hydrogenase phenotypes. Applied and Environmental Microbiology, Washington, v. 56, p. 224-229, 1990.

Germano, M.G.; Galli-Terasawa, L.V.; Chueire, L.M.O.; Hungria, M.; Bangel, E.V.; Campo, R.J. 2003. Identificação de estirpes de Bradyrhizobium japonicum / B. elkanii mais eficientes e competitivas para a cultura da soja e avaliação das respostas à reinoculação em áreas com populações estabelecidas distintas de Bradyrhizobium. In: Hoffmann-Campo, C.B.; Saraiva, O.F. (eds). Resultado de Pesquisa da Embrapa Soja - 2002. Microbiologia do Solo.. Londrina, Embrapa Soja. p. 42-59. (Embrapa Soja. Documentos, 216).

Graham, P.H.; Vance, C.P. Nitrogen fixation in perspective: An overview of research and extension needs. Field Crops Research, v. 65, p. 93-106, 2000.

Hameed, S.; Yasmin, S.; Malik, K.A.; Zafar, Y.; Hafeez, F.Y. Rhizobium, Bradyrhizobium and Agrobacterium strain isolated from cultivated legumes. Biology and Fertility of Soils, v. 39, p. 179-185, 2004. 
Hara, F.A.S.; Oliveira, L.A. Características fisiológicas e ecológicas de isolados de rizóbios oriundos de solos ácidos e álicos de Presidente Figueiredo, Amazonas. Acta Amazônica, v. 34, n. 3, p. 343-357, 2004.

Hara, F.A.S.; Oliveira, L.A. Características fisiológicas e ecológicas de rizóbios oriundos de solos ácidos de Iranduba, Amazonas. Pesquisa Agropecuária Brasileira, Brasília, v. 40, n. 7, p. 667-672, 2005.

Hungria, M.; Vargas, M.A.T. Environmental factors affecting grain legumes in the tropics, with an emphasis on Brazil. Field Crops Research, v. 65, p. 151-164, 2000.

Hungria, M.; Chueire, L.M.O.; Coca, R.G.; Megías, M. Preliminary characterization of fast growing rhizobial strains isolated from soyabean nodules in Brazil. Soil Biololy and Biochemistry., v. 33, p. 1349-1361, 2001.

KCS: Kovach Computing Services, 2009. MultiVariate Statistical Package. Virginia, USA. Disponível Online: www.kovcomp.co.uk/mvsp/. Acesso em: abril de 2009.

Lima, A.S.; Pereira, J.P.A.R.; Moreira, F.M.S. Diversidade fenotípica e eficiência simbiótica de estirpes de Bradyrhizobium spp. de solos da Amazônia. Pesquisa Agropecuária Brasileira, Brasília, v. 40, n. 11, p. 1095-1104, 2005.

Liu, J.; Wang, E.T.; Chen, W.X. Diverse rhizobia associated with wood legumes Wisteria sinensis, Cercis racemosa and Amorpha fruticosa grown in the temperate zone of the China. Systematic and Applied Microbiology, v. 28, n. 5, p. 465-477, 2005.

Martins, L.M.V.; Neves, M.C.P.; Rumjanek, N.G. Growth characteristics and symbiotic efficiency of rhzobia isolated from cowpea nodules of the northeast region of Brazil. Soil Biology and Biochemistry., v. 29, n.5/6, p. 1005-1010, 1997.

Martins, L.M.V.; Xavier, G.R.; Rangel, F.W.; Ribeiro, J.R.A.; Neves, M.C.P.; Morgado, L.B.; Rumjanek, N.G. Contribution of biological nitrogen fixation to cowpea: a strategy for improving grain yield in the Semi-Arid Region of
Brazil. Biology and Fertility of Soils, v. 38, n. 5, p.:333-339, 2003.

Norris, D. O.; Date, R. A. Legume bacteriology. In: Shan, N. H.; Bryan, W. W. ed. Tropical Pasture Research - Principles and Methods. Hurley: Commonwealt Bureau of Pasture and Field Crops, 1976. p. 134-174. (Bulletin, 51).

Saleena, L.M.; Loganathan, P.; Rangarajan, S.; Nair, S. Genetic diversity and relationship between Bradyrhizobium strains isolated from blackgram and cowpea. Biology and Fertility of Soil, v. 34, n. 4, p. 276-281, 2001.

Santos, C.E.R.S.; Stamford, N.P.; Neves, M.C.; Rumjanek, N.G.; Borges, R.V.; Freitas, A.D.S. Diversidade de rizóbios capazes de nodular leguminosas tropicais. Revista Brasileira de Ciências Agrárias, v. 2, n. 4, p. 249-256, 2007.

Silva, V.N.; Silva, L.E.S.F. \& Figueiredo, V.B. Atuação de rizóbio com rizobactéria promotora de crescecimento em plantas na cultura do caupi (vignia unguiculata [L.] Walp). Acta Scientiarum Agronomy, v. 28, n. 3, p. 407-412, 2006.

Somasegaran, P.; Hoben, H. J. 1985. Methods in legume-Rhizobium technology. NifTAL Project and MIRCEN, Hawaii, 365p.

Vieira, C. L. Efeito de estirpes de rizóbio em cultivares de caupi do agreste paraibano. Dissertação (Mestrado) em Microbiologia do solo, Universidade Federal de Pernambuco, Recife. 39p., 2007.

Vincent, J. M. 1970. A manual for practical study of root nodule bacteria. IBP Handbook N. 15. Blackwell Scient. Publ. 140p.

Xavier, G.R.; Martins, L.M.V.; Zilli, J.E.; Peixoto, R.C.; Rumjanek, N.G. 1997. Protocolo operacional cultivo de planta-isca para isolamento de rizóbio a partir de nódul de planta-isca. Seropédica: Embrapa-Agrobiologia, Dezembro, 1997. 7p. (Embrapa-CNPAB. Documentos, 43.

Zhang, W.T.; Yang, J.K.; Yuan, T.Y.; Zhou, J.C. Genetic diversity and phylogeny of indigenous rhizobia from cowpea (Vigna unguiculata (L.) Walp.). Biology and Fertility of Soil, v. 44, n. 1, p. 201-210, 2007. 
Zilli, J.E.; Valisheski, R.R.; Freire Filho, F.R.; Neves, M.C.P.; Rumjanek, N.G. Assessment of cowpea rhizobium diversity in cerrado areas of northeastern Brazil. Brazilian Journal of Microbiology, v. 35, p. 281-287, 2004.

Zilli, J.E.; Valicheski, R.R.; Rumjanek, N.G.; Simões-Araújo, J.L.; Freire Filho, F.R.; Neves, M.C.P. Eficiência simbiótica de estirpes de Bradyrhizobium isolados de solo do Cerrado em caupi. Pesquisa Agropecuária Brasileira, v. 41, n. 5, p. 811-818, 2006.

Recebido: 03/04/2013

Received: 04/03/2013

Aprovado: 20/07/2013

Approved: 07/20/2013 